\title{
Environment, technology and sustainability: the development and management of well-irrigation in Guanzhong Plain in Qing China
}

\begin{abstract}
This paper presents a case study of the well irrigation in Guanzhong Plain during the Qing dynasty. The paper analyses the scales and results of well irrigation campaigns sponsored by the government in the mid-eighteen century and the late nineteenth century. Limited by the natural environment and technical conditions, the efficiency of well irrigation is poor. Farmers' choices also affect the development of well irrigation. Moreover, a lack of management led to the unsustainable use of groundwater. Historical groundwater policies were mainly aimed at increasing agricultural production. Policies should be made according to local conditions. It is important to ensure the sustainable development of groundwater.
\end{abstract}

Keywords

Central China $•$ well irrigation $•$ environment $\bullet$ technology $\bullet$ sustainability

(C) University of Warsaw - Faculty of Geography and Regional Studies
Shengrong Gao, Xiaohui Ding

Northwest Institute of Historical Environment and Socio-economic Development, Shaanxi Normal University, Xi'an, China e-mail: gaoshengrong@snnu.edu.cn; xhding@snnu.edu.cn

Received: 7 November 2018

Accepted: 23 January 2019
Introduction

Agricultural water use in many parts of the world, especially in arid and semi-arid areas, has played an important role in the development of agriculture. In areas where surface water is scarce, irrigation depends mainly on groundwater. In some regions, groundwater is an important source of water for food security, poverty alleviation, and good sanitary conditions. Groundwater needs little transport, being produced where needed. It offers irrigation to an individual farmer "on demand", something few surface systems can do (Shah et al. 2003). However, due to the restriction of various factors, the development of groundwater for irrigation may not be satisfactory in a particular region or period. Caswell and Zilberman theoretically show that the adoption decision is affected by well depth (i.e. water price), land quality, and crop type (Caswell \& Zilberman 1985).

It is useful to provide some historical perspective on the issues of technological choice, resource management, and the sustainability of agricultural systems. This article examines groundwater policies and technologies, first through a historical perspective and then by undertaking an environmental-level analysis to explore the factors driving the development of using groundwater for irrigation by drilling wells in Guanzhong Plain in north-west China, in a particular early modern state, that of China under the Qing dynasty (1644-1911). By analysing the history of groundwater policy and techniques, and investigating farmers' perspectives on groundwater development, this study aims to produce scientific knowledge to better inform the sustainable development of groundwater.

\section{Study area}

These events took place in Guanzhong Plain of Shaanxi province. The Guanzhong Plain in central Shaanxi, which covers an area of $20,000 \mathrm{~km}^{2}$, is one of the largest basins of the Yellow River catchment in China. The Guanzhong Plain is dominated by the north-west-oriented valley between the Qinling Mountains in the south and Beishan Mountains in the north. On both the north and south sides of the valley, the basin turns from a pluvial plain into a loess tableland and valley terrace (Wang et al. 2013). The Guanzhong Basin is filled with Quaternary alluvial, fluvial and loess deposits with a total thickness of approximately 1,000 $\mathrm{m}$ capable of storing a significant amount of groundwater. The climate in Guanzhong Plain is warm-temperate, sub-humid, continental monsoon with cold winters and hot summers. The mean annual temperature varies from $7.2^{\circ} \mathrm{C}$ to $15.2^{\circ} \mathrm{C}$ (Wu \& Sun 2016). The mean precipitation ranges from $543.6 \mathrm{~mm}$ to 863.0 $\mathrm{mm}$ per annum, with about half of the precipitation falling in July, August, and September. The annual rate of evaporation is in the range of $900 \mathrm{~mm}$ to $1,200 \mathrm{~mm}$ (Wu et al. 2017). There were five $\mathrm{Fu}$ (the second level in the administration frame) and forty-one counties (the third level in the administration frame) in Guanzhong Plain during the Qing dynasty (Figure 1). The Guanzhong Plain which is a typical semi-arid area, is important for cereal production.

Droughts in Guanzhong Plain are particularly long-lasting. In the past 500 years, more than ten severe droughts in the area have lasted over one year. Drought that impacted the Guanzhong area gave rise to a typical agricultural crop structure that prioritised dry farming. Dry grain included varieties such as wheat, beans, shu (broom corn millet), ji (millet) and sorghum. The wheat planting area was the most widely developed. Irrigation is very important to the development of agriculture in Guanzhong Plain. The fertile fields have been irrigated since the construction of the Zhengguo Canal in 246 BC. During the Qing dynasty, Guanzhong Plain was 


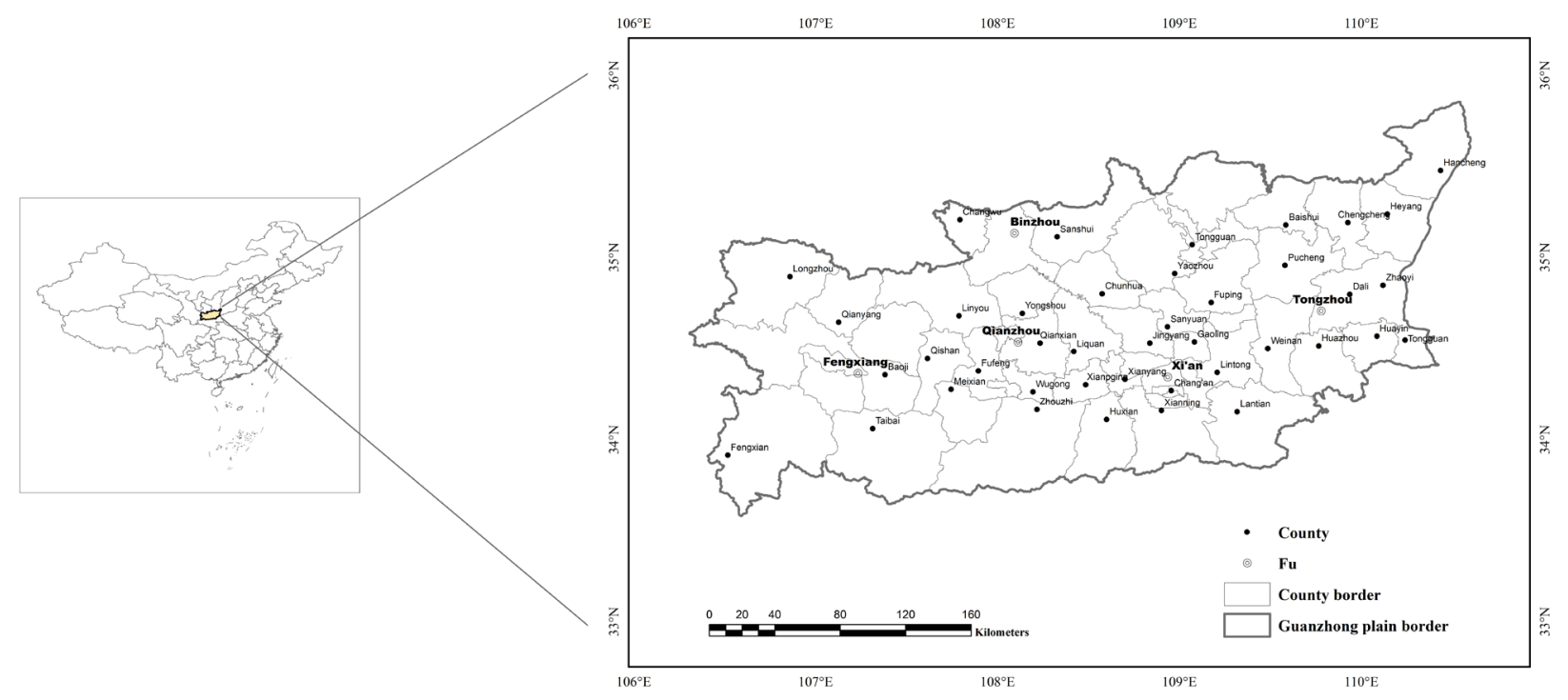

Figure 1. Geographical position and administrative division of the Guanzhong Plain. Source: Tan QX 1987, The Historical Atlas of China, China cartographic publishing house, Beijing, Vol.8, pp.26-27

by far the most densely populated region of Shaanxi, and it was not only subject to extreme rainfall, but due to the lack of water transportation, it was also fairly difficult to mobilise massive aid there from outside in case of serious famine. Improvements in the physical efficiency of irrigation systems are often suggested as a means of coping with short water supplies. When surface water resources were scarce, some people thought of using underground water.

The well irrigation campaign in the Qing dynasty

There were two well drilling campaigns sponsored by the Qing government: one during the period of the Qianlong emperor (1736-1796) and one during the period of the Guangxu emperor (1875-1908). The scales and results of the well irrigation were different.

There were successive years of drought in Guanzhong Plain during the early eighteenth century (Ge etal. 2013). The drought had severely disrupted agricultural production. Cui Ji (1693-1750), a governor of Shaanxi thought that the most urgent task was to improve irrigation. He launched a campaign to drill new wells in the second year of the Qianlong emperor's reign (1737). In terms of quantity, the first report announced that over 65,870 wells had been drilled in those counties at that time (Table 1). However, things clearly did not go so smoothly. Cui was too impatient to obtain results, and his subordinates exaggerated their success by claiming higher numbers of wells. Furthermore, some wells were left unfinished. Some drilled wells did not work. In fact, his successor found that only approximately half of the wells that had been drilled were fit for irrigation (Song \& Wu 1990).

In the early years of the Qianlong emperor's reign (1747), there were over 136,900 wells in Shaanxi province (Song \& Wu 1990). There is no record of the specific number of wells in Guanzhong Plain due to the absence of historical data.

In the latter part of the nineteenth century, Shaanxi suffered a severe drought. In the third year of Guangxu emperor's reign (1877), Tan Zhonglin and Zuo Zongtang, the senior officers who managed the affairs, encouraged the farmers to drill wells to ensure production through effective irrigation (Tan 1966). Zuo proposed a policy of encouraging farmers to develop well irrigation. After that, approximately 4,000 wells were drilled in Guanzhong Plain (Table 2). The quantity and the scales of well irrigation drilled during the period of the Guangxu emperor were fewer and smaller than that drilled during the period of the Qianlong emperor.

Because of historical data limitations, it is difficult to trace the development process of well irrigation in the Qing dynasty. There were 27,500 wells in the whole province in 1949 when the People's Republic of China was founded. At that time, the depth of the wells was limited, and the structures were simple. Most of the wells were tujing (wherein the farmer drills a round pit until water comes out; this kind of well is easy to damage) and lacked mechanical pumping systems, which resulted in inadequate water production of the wells. Those wells were mainly distributed at the edge of the alluvial fan and Weihe River terraces in the Guanzhong Basin (Shaanxi local chronicle Compilation Committee 2000).

Looking through the development of irrigation in the Guanzhong area, under the government's strong advocacy, a certain number of new wells had been drilled during the Qianlong period. However, this trend did not continue, and was followed by a decline. Although the government of the Guangxu emperor had strongly advocated for irrigation, the result was far inferior to that of the government of the Qianlong emperor. There were more than 136,900 wells in the Qianlong period, and the number was down to 27,500 in 1949 . Perhaps the development of well irrigation was not as positive as we thought.

The groundwater environment in Guanzhong Plain

Well yield and depth of groundwater have an impact on the development of well irrigation (Foster, Brozović \& Butler 2015). Surface water, precipitation, and undercurrents are the main determinants of groundwater in areas irrigated by wells. Whether an area can develop well irrigation depends on groundwater conditions and reserves. There is rich groundwater in the Guanzhong Plain and valley terraces and relatively poor groundwater in the loess plateau region (Nie 1981) (Figure 2).

However, not all places are suitable for well irrigation in Guanzhong Plain. In some places it is hard to dig wells because the soil is very thick and the groundwater is buried too deep. In the fifth year of the Qianlong emperor's reign (1740), E Mida, Chuanshan Zongdu (the governor of the Sichuan and Shaanxi 
Table 1. The Statistics on New Wells Drilled in 1737

\begin{tabular}{|c|c|c|c|c|c|}
\hline Region & Number & Region & Number & Region & Number \\
\hline Xi'an Fu & 50540 & Tongzhou Fu & 7190 & Fengxiang Fu & 2800 \\
\hline Xianning County & 5700 & Dali County & 2600 & Fufeng County & \\
\hline Chang an County & 13900 & Huazhou & 1470 & Qishan County & \\
\hline Xianyang County & 3640 & Zhaoyi County & 1790 & Mei County & \\
\hline Jingyang County & 2190 & Pucheng County & 770 & Baoji County & \\
\hline Zhouzhi County & 6880 & Hancheng County & 230 & Qianyang County & \\
\hline Hu County & 8490 & Tongguan & 330 & Qianzhou Fu & 5200 \\
\hline Xingping County & 4590 & & & Wugong County & \\
\hline Fuping County & 220 & & & Binzhou Fu & 140 \\
\hline Gaoling County & 820 & & & Sanshui County & \\
\hline Weinan County & 3700 & & & Changwu County & \\
\hline Liquan County & 410 & & & & \\
\hline
\end{tabular}

Source: Records in local chronicles (Song \& Wu 1990)

Note: Due to historical data limitations, there is no record of well drilled in the counties of Fengxiang Fu, Qianzhou Fu and Binzhou Fu.

Table 2. The Statistics on New Wells Drilled in 1877

\begin{tabular}{|c|c|c|c|}
\hline Region & Number & Region & Number \\
\hline Xi'an Fu & 1500 & Tongzhou Fu & 3500 \\
\hline Xingping County & 500 & Dali County & 3000 \\
\hline Liquan County & 500 & Zhaoyi County & 500 \\
\hline Jingyang County & 500 & & \\
\hline
\end{tabular}

Source: Records in local chronicles (Song \& Wu 1990)

provinces), investigated well irrigation in Guanzhong Plain. He thought the soil was thick and the groundwater was deep; in some places of Xi'an Fu, the depth of a well had to be approximately 5-7 zhang (17.5-23.5 metres). When drought occurred, the water in the well could only irrigate several $m u$ (a unit of area; one $m u$ equals 0.0667 hectares) (E 1740). In the eighth year of the Qianlong emperor's reign (1743), Se Lenge, Shaanxi Xunfu (the governor of Shaanxi province), said that the soil was thick and the groundwater was deep, leading to the drilling of wells that failed to even reach a depth of more than 10 zhang (35 metres) in some areas (Se 1743). In Chengcheng County, wells had to be drilled 40 zhang (140 metres) deep to access water (Dai, Hong \& Sun 2007). Moreover, the area could not be drilled easily because of the thick soil in Mei County; it was the same in Yongshou County (Liu 1990).

Furthermore, some places were unsuitable for well irrigation because of water quality. Compared with rivers, groundwater temperature is low and salinity is high, which is harmful to crops. In the third year of the Qianlong emperor's reign (1738), Zha Alang, Junzheng Zongdu (the governor in charge of military and political affairs), told the emperor that in Shaanxi province, the river was "sweet and warm" and the well water was "bitter and cold", so it could not irrigate, even if the wells were drilled
(Zha 1738). Ferdinand Von Richthofen (1833-1905), a German geologist, conducted an investigation on the Weihe Plain, which was originally a large lake connected to the sea, and cotained many quality bitterns; as the geological composition changed, the soil gradually improved, suitable for cultivation, but some places in Pucheng County, Fuping County and Weinan County could not be cultivated because of brine. In some places in Jingyang County, Sanyuan County and Dali County, the groundwater could not be used to irrigate because of water salinity, even after drilling dozens of chi (10 metres deep) (An 2006).

\section{The technology of well irrigation}

The development of irrigation technology is closely related to the development of agriculture. While drought appears to have triggered some changes in irrigation, drought alone did not bring about wholesale changes in technology. In the Qing dynasty, the technologies for drilling wells and raising water from the wells were very important to the development of using groundwater to irrigate.

In 1732, Wang Xinjing (1656-1738), a local scholar living in Guanzhong Plain, wrote a book named Advantages of Wells (ed. Wang, 1966). In this book, he thought that the underground water would never be exhausted. One of the major advantages of well irrigation was that it continued to provide water in times of drought when the other sources of irrigation had dried up, especially in Shaanxi. If the well could be drilled in the right area, the people in that area could enjoy long-term benefits. According to Wang's own careful investigations in the field, a well could be drilled wherever water was found at a depth of no more than 4 or 5 zhang (14 or 17.5 metres). He proposed facing the wells with bricks and equipping them with beam structures supporting a jiegao (a mechanism for raising water by leverage) or a drum with a lulu (a mechanism for raising water using a pulley). The cost of drilling these types of wells did not exceed a dozen taels of silver, or 3 to 5 taels if the nature of the soil made brick facing unnecessary, and the equipment did not cost more than a tael. Such wells could irrigate from 6.7 to $2.3 \mathrm{mu}$, yielding up to 15 dan 


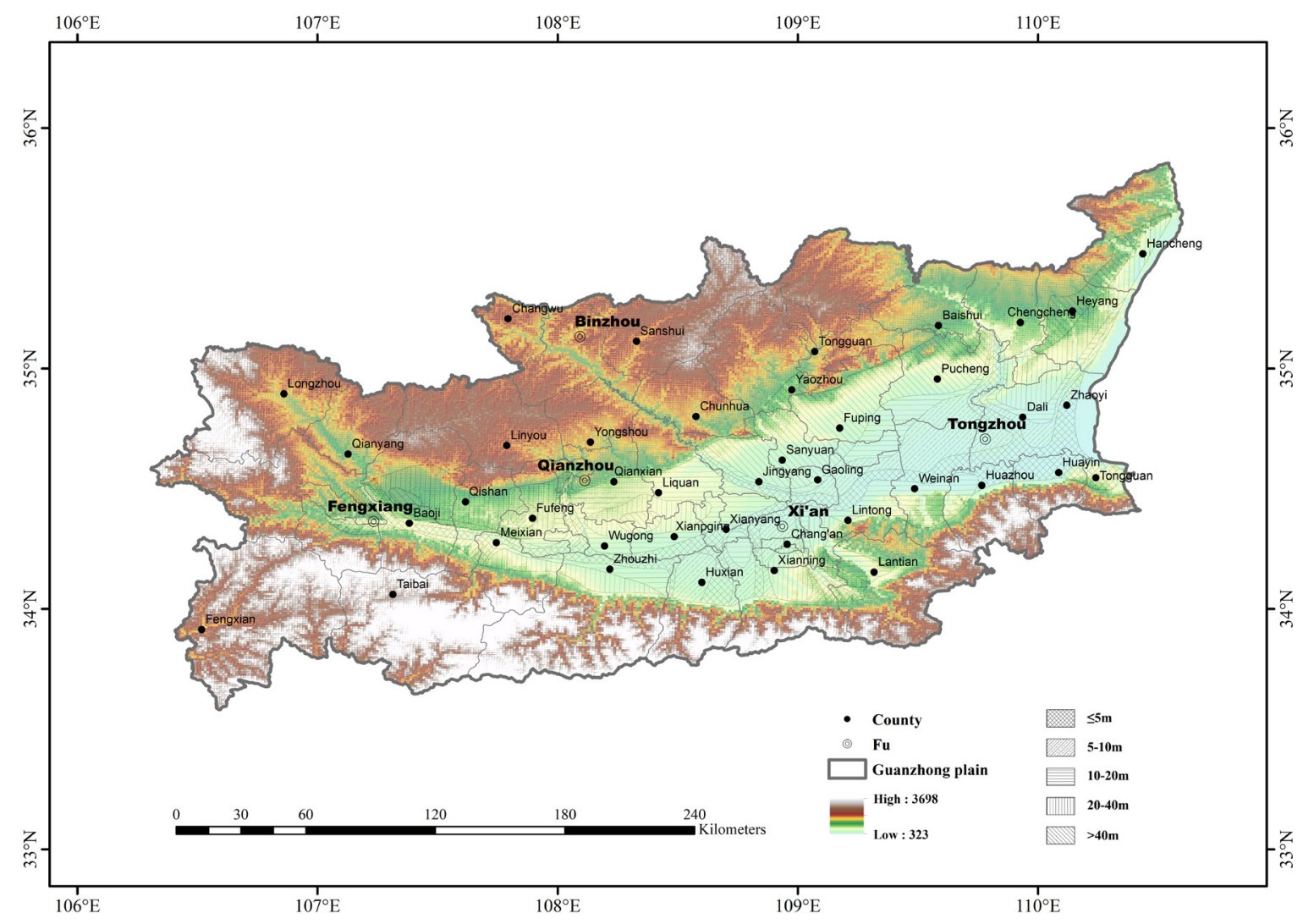

Figure 2. The groundwater depth in the Guanzhong Plain. Source: Geospaital Data Cloud: http://www.gscloud.cn/; Duan, L, Wang, WK, Wang, YL \& Yang, ZY 2007, 'Evaluation and analysis of groundwater resources in Guanzhong basin', Agricultural Research in the Arid Areas, Vol.25, no.5, pp. 172-175

(a unit of dry measure for grain, one dan is equal to $28 \mathrm{~kg}, 15$ dan amounts to $420 \mathrm{~kg}$ ) of unhusked grain or even up to 25 dan $(700 \mathrm{~kg})$ if a sufficient quality and quantity of labour was applied. It should be noted that $15-20$ dan $(420-560 \mathrm{~kg})$ was enough to feed a family of eight.

The difficulty was greater in the case of a well equipped with a water wheel instead of a jiegao or a lulu. In such cases, the depth needed to be approximately 3 zhang ( 11 metres) and the well always needed to be faced with bricks. The cost of construction would vary from 7 to more than 10 taels of silver depending on the depth. A water wheel also cost about 10 taels of silver. However, with this equipment, a well could water from 20 to $40 \mathrm{mu}$ depending on its depth (the shallower the depth the larger the irrigated area). This represented a yield of up to 100 dan $(2,800 \mathrm{~kg})$ of grain, even in a year of dearth, provided that the water and fertilizer were applied at the right time and the fields were correctly tended. Such large wells equipped with water wheels were especially suitable, Wang said, where their use had to be shared by several families in sparsely populated districts (Wang 1966). Such construction is a common technology in today's world but it was hard to achieve at that time. The Wei Valley underground waters have been heavily used since modern drilling techniques and pumps activated by engines have become widely available for drilling in recent decades (Sun 2005).

In the Qing dynasty, irrigation methods included border irrigation, furrow irrigation, basin irrigation and flood irrigation, whose advantages included simple operation and low cost management and whose disadvantages included low irrigation efficiency and large water loss during the irrigation process. Due to the lack of historical data, we cannot accurately calculate the efficiency of well irrigation in the Qing dynasty. In 1949, the depth of the wells was limited, and the structure was simple; most of the wells were soil wells. The construction of the wells mainly used manpower or animal power to raise water, so the irrigation area and efficiency were limited. The average area a single well equipped with a water wheel irrigated was $20 \mathrm{mu}$, and the total irrigation area was 55,000 $\mathrm{mu}$, which was mainly distributed in the marginal zone and the river terrace in the Guanzhong Basin (Nie 1981). Even in 2009, the efficiency of well irrigation was still not high because of extensive water management, a great loss of irrigation in the field, leakage and evaporation (Cao 2011).

One lag in technology has been the bottleneck of well irrigation development in Guanzhong Plain. Even today, people are still trying to improve the technology of well irrigation in order to improve water efficiency.

\section{The choice of the local people}

Farmers can respond to drought in a variety of ways. In the short term, they can reduce water application, fallow acreage or change crops. With their eyes on a more distant horizon, they can also adopt different irrigation systems (Schuck et al. 2005). After examining the well irrigation development in Guanzhong region, a few questions need to be asked. Since scholars and officials repeatedly emphasized the benefits of well irrigation, some local governors strongly advocated for and implemented well irrigation. In fact, almost every family could afford to drill a small well, which was far easier and cheaper than drainage pipes, but the local people did not have enough enthusiasm. Why was the actual 
outcome of well irrigation not booming? Why did well irrigation not develop as expected?

In the Qing dynasty, some farmers did not like to drill wells because the pay and benefits were not proportional to input. The cost of drilling a well was an income of several $m u$, but it could only irrigate limited areas during a drought. The tools for drilling wells, such as lulu and jiegao were not easy to control. Two labourers working for one day could irrigate 1 to $4 \mathrm{mu}$. In the Guanzhong area, two or three labourers farmed approximately one hundred $m u$. Even if a well could irrigate $4 \mathrm{mu}$, nearly a month was needed to do it. In order to not miss any season for farming, the farmer would have to hire other labourers, and the cost for hiring labourers was high. In such a situation, the farmers detested having to start new enterprises (Zhang \& Gu 1777).

Furthermore, in many cases the peasants simply did not have the resources necessary to implement well irrigation efficiently. If water was to be obtained from wells in sufficient quantity to achieve reliable irrigation, it had to be pumped with machinery powered by animal force, but only rich households could afford the machinery and the animals. By contrast, when water was elevated with lulu or jiegao, it needed to be activated by three or four people working in shifts. As a result, a common household could manage only one or two wells. The effects of well irrigation did not satisfy the farmers.

During a drought, farmers have to evaluate the effectiveness of the entire farm's irrigation infrastructure, choosing to upgrade some portions and downgrade others depending upon the relative cost of changes to each different system. For some farmers in Guanzhong Plain, it is a rational choice to not select well irrigation for upgrading.

\section{A lack of management}

Irrigation management aimed to address the protection and utilisation problems related to water resources and to achieve sustainable area development. In Guanzhong Plain, the most widespread source of irrigation water was surface water. The most common irrigation system was canal irrigation. For a long period of history, there was a set of management methods for canal irrigation to achieve sustainability and effectiveness in irrigation. Well irrigation usually ran on a very small scale used by one or several families. During the Qing dynasty, although the farmers drilled many wells, as encouraged by government policies, the government did not issue corresponding management measures to protect and maintain the wells. Most wells were damaged by the influence of environmental factors in a short period of time. A lack of management led to the unsustainable use of groundwater.

\section{Conclusions}

To increase land productivity, large-scale, officiallysponsored campaigns to develop well irrigation occurred in Guanzhong Plain in two periods during the Qing dynasty. A certain number of new wells had been drilled during the Qianlong period. However, this trend did not continue and was followed by a decline. Although the scale and results of well drilling were different, drilling did not develop sustainably. As a limitation of the natural environment and technical conditions, we can infer that the efficiency of well irrigation in Guanzhong Plain during the Qing dynasty was low and that the benefits of well irrigation were limited. Therefore, the first choice for most of the farmers was not well irrigation but channel irrigation. Still, there was a lack of management that led to the unsustainable use of groundwater.

History is a mirror of the future. Regardless of the past or present, to improve the benefits and efficiency of environmental resources, policies should be made according to local conditions. In the long run, a more comprehensive sustainable groundwater management policy, with strong institutional support and the involvement of all stakeholders, is needed.

\section{Acknowledgements}

This work was supported by the Chinese Ministry of education of Humanities and Social Sciences Project [Grant No. 16YJC770003] and the Fundamental Research Funds for the Chinese Central Universities [Grant No. 16SZYB22].

\section{References}

An, $\mathrm{H}$ 2006, 'A discussion of reclaim and cultivate Wasteland in Northwest China', Economic History Compilation Northwest of China in Modern Times, vol. 4, p. 173.

Cao, N 2011, 'Analysis of water efficiency of well irrigation in Guanzhong area', Groundwater, vol. 33, no. 5, pp. 81-82.

Caswell, M \& Zilberman, D 1985, 'The choices of irrigation technologies in California', American Journal of Agricultural Economics, vol. 67, no.8, pp. 223-234.

Dai, Z, Hong, LJ \& Sun, XY 2007, Chengcheng annals in Qianlong Period, Phoenix Press, Nanjing.

E, MD 1740, 'Memorial copies of Chuanshan Zongdu', in Memorial Copies from the Grand Council Archives, no. 03-9701-044, The First Historical Archives of China, Beijing.

Foster, T, Brozović, N \& Butler, AP 2015, 'Analysis of the impacts of well yield and groundwater depth on irrigated agriculture', Journal of Hydrology, vol. 523, pp. 86-96.

Ge, Q, Hao, Z, Zheng, J \& Shao, X 2013, 'Temperature changes over the past 2000 year in China and comparison with the Northern Hemisphere', Climate of the Past, vol.9, no.3, pp. 1153-1160.

He, CL 1966, Huangchao jingshi wenbian, Wenhai Press, Taibei.

Liu, YY 1990, Yongzheng Shaanxi Tongzhi, Lanzhou Ancient Books Press, Lanzhou.

Nie, SR 1981, Geography of Shaanxi Province, Shaanxi People's Publishing House, Xi'an.
Schuck, EC, Frasier, WM, Webb, RS, Ellingson, LJ \& Umberger WJ 2005, 'Adoption of more technically efficient irrigation systems as a drought response', Water Resources Development, vol. 24, no.4, pp. 651-662.

Se, LG 1743, 'Memorial copies of Shaanxi Xunfu', in Memorial Copies from the Grand Council Archives, no. 03-9725-043, The First Historical Archives of China, Beijing.

Shaanxi local chronicle Compilation Committee 2000, Shaanxi Shengzhi Dilizhi, Shaanxi people's Publishing House, Xi'an.

Shah, T, Aditi, DR, Qureshi, A \& Wang, J 2003, 'Sustaining Asia's groundwater boom: An overview of issues and evidence', Natural Resources Forum, vol. 27, no.2, pp. 130-141.

Song, BL \& Wu, TX 1990, Minguo xuxiu Shaanxi tongzhigao, Lanzhou Ancient Bookstore, Lanzhou.

Sun, SX 2005, 'The development of well irrigation in Guanzhong area', Groundwater, vol. 27, no.1, pp. 10-18.

Tan, BZ 1966, The memorials to the emperor of Tan Zhonglin, Wenhai Press, Taibei.

Wang, W, Duan L, Yang, X \& Tian, H 2013, 'Shallow groundwater hydro-chemical evolution and simulation with special focus on Guanzhong Basin, China'. Environment Engineering and Management Journal, vol.12, no.7, pp. 1447-1455.

Wang, XJ 1966, 'Advantages of Wells', in Huangchao Jingshi Wenbian, ed He Changling, Wenhai Press, Taibei, vol. 38, pp.7-14. 
Wu, H, Qian, H, Chen, J \& Huo, CC 2017, 'Assessment of agricultural drought vulnerability in the Guanzhong Plain, China', Water Resour Manage, vol. 31, pp. 1557-1574.

$\mathrm{Wu}, \mathrm{JH}$ \& Sun, ZC 2016, 'Evaluation of shallow groundwater contamination and associated human health risk in an alluvial plain impacted by agricultural and industrial activities, midWest China', Exposure and Health, vol.8, no.3, pp. 311-329.

Zha, AL 1738, 'Memorial copies of Chuanshan Zongdu', in Memorial Copies from the Grand Council Archives, no. 04-01-11-0001-010, The First Historical Archives of China, Beijing.

Zhang, X \& Gu, SL 1777, Xingping Annals in Qianlong Period, thread-bound edition, Vol.3, pp.79-134. 